\title{
Effect of feed additive supplementation on bovine subclinical mastitis
}

\author{
Imane Lamari, Nora Mimoune $e^{*}$ and Djamel Khelef
}

\begin{abstract}
Bovine mastitis is an important commercial and sanitary cost in milk production. The prevention and treatment of this disease is essentially based on the use of antibiotics that have limited effectiveness and can negatively affect milk quality. The aim of this study was to evaluate the effectiveness of an alternative treatment based on a symbiotic in the control and prevention of subclinical mastitis (SCM), and in the improvement of the quality of milk produced on a dairy farm in north-central Algeria. The milk of 68 cows was collected and analysed by somatic cell count and bacteriological analysis. Three samples were taken at one-month intervals. The first sample was taken before the administration of a feed additive (SYMBIOVEBA ${ }^{\circledR}$ ) to lactating dairy cows. Animals were divided into two groups to study the effects (curative and preventive) of the symbiotic. Each group was further divided into two subgroups, where one received
\end{abstract}

the symbiotic and the other was the control. The prevalence of subclinical mastitis at this farm was $33.82 \%$. Bacterial identification was performed using classical methods only on the group of cows with mastitis; a total of 13 bacterial species were isolated from the three samples. Staphylococci were dominant, with a frequency of $45 \%$, followed by Enterobacteriaceae (40\%). These rates were considerably lower in both subgroups, though treated cows showed $100 \%$ cure rate for both Staphylococci and Enterobacteriaceae. Individual somatic cell count (ISCC) was performed on all three samples and in both groups, and revealed a cure threshold (S) of 200,000 cells $/ \mathrm{mL}$, and a $100 \%$ cure rate for the SYMBIOVEBA ${ }^{\oplus}$-treated cow subgroup compared to $62.5 \%$ for the control subgroup $(P<0.05)$.

Key words: dairy cow; subclinical mastitis; bacteriology; ISCC; symbiotic

\section{Introduction}

Mastitis is the primary cause of economic losses for dairy ruminant farms, incurring costs of several million euros per year (Gračner et al., 2006; Maćešić et al., 2012; Saidi et al., 2013;

Kovačić et al., 2019; Nedić et al., 2019; Cvetnić et al., 2016a, b; Đuričić et al., 2017). Costs are due to a drop in milk production, issues of raw material processability, premature culling of

Imane LAMARI, National high school of veterinary medicine, SPA Laboratory, Algiers, Bab-Ezzouar, Algeria; Nora MIMOUNE*, (Corresponding author: nora.mimoune@gmail.com), National high school of veterinary medicine, SPA Laboratory, Algiers, Bab-Ezzouar, Algeria, Institute of Veterinary Sciences, Laboratory of Biotechnologies related to animal Reproduction, University of Blida 1, Algeria; Djamel KHELEF, Institute of Veterinary Sciences, Laboratory of Biotechnologies related to animal Reproduction, University of Blida 1, Algeria 
animals with clinical or chronic mastitis, treatment costs (veterinary products and fees), and financial penalties on milk quality based on somatic cell count (SCC) (Benić et al., 2018; Burović, 2020). Many health problems can also result from the lower quality of the raw material. Indeed, the presence of bacteria in milk following the milking of infected animals can lead to contamination throughout the dairy chain, causing food poisoning (Cvetnić et al., 2016b; Saidi et al., 2021a).

Clinical mastitis is a serious problem on dairy farms and can be visually detected, whereas detection of SCM requires monitoring of milk cell counts by indirect and/or direct methods (M'sadak et al., 2014; Maćešić et al., 2016; Đuričić et al., 2017; Turk et al., 2017).

Meanwhile, consumer expectations of food are changing, with increasing questioning of the quality of what is being offered by current agriculture, including animal production. There is also a limited fear among the population of the risk of antibiotic residues in food resulting from the systematic use of these molecules in animal husbandry (Cvetnić et al., 2016c; Saidi et al., 2021b). In order to keep up with consumer expectations, it seems necessary to reduce the number of treatments per cow, which of course means better reasoning for the treatments, above all to reduce the prevalence of new infections. However, mastitis is a multifactorial problem that can only be resolved by addressing some of the risk factors present in animal husbandry (Turk et al., 2012; Kleczkowski et al., 2017). This is why, apart from the identification of the mechanisms of infection propagation, it becomes necessary to set up prevention measures, such as feed additives, that improve the zootechnical performance of cow and improve individual resistance to pathogens (Đuričić et al., 2017).

The objectives of this study were to evaluate the prevalence of SCM through the measurement of individual somatic cell count (ISCC), to identify the bacteria involved, and to study the evolution of bacteriology after administration of a symbiotic aimed at improving the zootechnical performances of the herd, thus determining its curative or preventive effects.

\section{Materials and Methods}

\section{Study farm}

This study began in February 2017 and was completed in May 2017 on a farm located in the Tipaza region (northcentral Algeria). The cows on the farm are of the Fleckvieh breed imported from Austria. They live in a free stall building with natural ventilation, the floor is equipped with a sleeping mat, and cleaning is performed by an automatic scraper 3 times per day.

Milking is done twice a day by a $2 \mathrm{x}$ 5 automatic milking machine. Mastitis cows are treated in the pot with two extra claws. All milking operations are performed by the farm technician.

\section{Animals included in the study}

Pre-selection was conducted for all cows in the herd in the lactation phase. The exclusion criteria were: local or general antibiotic treatment, cows with inter-current disease and cows during dry-off. Finally, 68 lactating cows were included in the study, where 45 received the symbiotic once a month after the first milk sampling; This represented a sampling rate of about $87 \%$ for the lactating cows (78 cows), and about $45 \%$ for all the cows of this farm with a total of 150 cows.

\section{Methods \\ Mastitis case definition and cure evaluation criteria}

In this experimental plan, mastitis was defined as an udder with a cell count greater than or equal to the threshold 
(S) for cure or non-infection, i.e., 200,000 cells/mL of milk (Boutet et al., 2006).

Each case of SCM was then defined as the starting point for the routing of samples for bacteriology. Cow recovery was assessed using CCSI in relation to the threshold (S) as detailed in the table below.

Table 1. Evaluation criteria for udder recovery

\begin{tabular}{|c|c|c|}
\hline $\begin{array}{c}\text { CCSI on } \\
\text { D0 }\end{array}$ & $\begin{array}{c}\text { CCSI on } \\
\text { D64 }\end{array}$ & Evaluation \\
\hline$\geq S$ & $\geq S$ & Not recovered \\
\hline$\geq S$ & $<S$ & Apparent recovery \\
\hline$<S$ & $<S$ & Clean \\
\hline$<S$ & $\geq S$ & Infection \\
\hline
\end{tabular}

The bacteriological recovery of the udders, on the other hand, implies the absence of bacteria in the milk sample analysed on day 64 (D64).

\section{Experimental design Samples}

Time of sampling

The evolution of SCM was monitored at the microbiological and cellular level by taking three milk samples at intervals of approximately 1 month between samples; i.e., on day 0 (D0; where the cell count allowed for definition of cow subgroups), then on day 31 (D31), and finally on day 64 (D64).

Milk samples were taken from the 68 cows selected for this study, in order to first perform the somatic cell count and thus determine the infected udders. This first sample was the starting point of the udder infection evaluation. Samples with a cell count of or exceeding 200.000 cells/ $\mathrm{mL}$ were sent to the laboratory and subjected to bacteriological examination. The sample volume was approximately 20 millilitres. Each udder was then resampled approximately one month after the first sample was taken to perform the cell count and bacteriological analysis.

The final sample was taken 1 month after the second sample to perform the final cell count and bacteriological examination in order to estimate the effect of the symbiotic additive on the performance of dairy cows and their subsequent resistance to pathogens.

All samples were kept at a temperature of $4^{\circ} \mathrm{C}$ and shipped to the laboratory within 4-5 hours.

\section{Addition of symbiotics The additive}

The additive used in this study was SYMBIOVEBA ${ }^{\circledast}$ (MARCOPOLO Environmental Group), a purely biological feed additive for veterinary use. After oral administration, this additive rebalances rumen $\mathrm{PH}$, improves zootechnical performance, prevents digestive disorders, strengthens the immune system, and maintains the good general condition of the animal.

The composition of this product is as follows: medicinal plants (Taraxacum officinalis, Zingiber officinalis), probiotics (Lactobacillus \& Saccharomycess cervicia), enzymes, plant extracts and water, obtained with an exclusive MESEN patented process.

\section{Additive administration}

The addition of the symbiotic to the cows' diet was for $2 / 3$ of cows with a cell count was greater than 200.000 cells/ $\mathrm{mL}$, and $2 / 3$ of the cows with a cell count of less than 200.000 cells/ml. This was done once a month, in accordance with the described dosage of this symbiotic, after the first two samples: D0 just after the first milk sampling and the first cell count, and D31 after the second sampling

Therefore, the test population was divided into four subgroups based on cell count in order to clearly demonstrate the effect of the symbiotic on resistance to udder infections in different situations. 
Table 2. Distribution of the symbiotic (SYMBIOVEBA ${ }^{\circledR}$ ) on the four subgroups of lactating cows

\begin{tabular}{|c|c|c|c|c|}
\hline Group & SCC & Subgroup & Treatment & Number of cows \\
\hline \multirow{2}{*}{1} & \multirow{2}{*}{$\geq 200.000$ cells $/ \mathrm{mL}$} & A (Test) & Symbiotic & 15 \\
\cline { 3 - 5 } & B (Control) & None & 8 \\
\hline \multirow{2}{*}{2} & $<200.000$ cells $/ \mathrm{mL}$ & C (Test) & Symbiotic & 30 \\
\hline & D (Control) & None & 15 \\
\hline
\end{tabular}

Following this distribution, two groups were formed:

1. Study of the curative effect of the symbiotic within Group 1 initially affected by mastitis and divided into the test (A) and control (B) subgroups, and

2. Study of the preventive effect of the symbiotic within Group 2 initially free of mastitis and divided into the test (C) and control (D) subgroups.

\section{Cell count}

The somatic cell count was performed on site at the farm, using a DeLaval Cell Counter ${ }^{\circledR}$ device. Cell counts were performed on all three monthly samples in both groups.

\section{Bacteriological examination}

Bacteriological examination was carried out at the microbiology laboratory of the Salim Zemirli Hospital (Algiers, Algeria) on all the monthly samples of Group 1.

During the first reading at 24 hours, all types of isolated colonies were transplanted onto Columbia agar to obtain a pure culture. In the absence of visible bacterial growth, the enrichment broth was transferred to $5 \%$ sheep blood Columbia agar.

On the second reading at 48 hours, direct isolation and post-enrichment culture was observed. If new colony types were observed, they were isolated as before. At this stage, the reading of the direct isolation was complete and sample quality could be determined. Any isolation of more than two colony types should be considered contaminated. In this study, we consider that samples with two colony types were bi-microbial infections.

Table 3. Evaluation of sample quality laccording to COFRAC/CNEVA*)

\begin{tabular}{c|c|}
$\begin{array}{c}\text { Number } \\
\text { of types of } \\
\text { colonies } \\
\text { isolated }\end{array}$ & Conclusion \\
\hline 0 & Sterile sample \\
\hline 1 & Bi-microbial contamination \\
\hline 2 & Or infection \\
\hline$>2$ & Contamination of the sample \\
\hline * COFRAC/CNEVA 1996: Pr 116/00BA 140/00, Isolation \\
and identification of the main mastitis germs in \\
ruminants.
\end{tabular}

When direct isolation revealed bacteria, enrichment was not taken into account. In the same way, any result where no culture was obtained directly and where the bacteria isolated after enrichment was not an Enterobacterium could be considered questionable. When no culture was obtained directly and an Enterobacterium was isolated after enrichment, this bacterium was considered responsible for the mastitis. This precision is necessary because Seynod's LIDAL always provides coupled results of direct isolation and 
enrichment (Noireterre, 2006). These results require interpretation.

\section{Identification}

Identification to the genus level was carried out by the appearance of colonies on agar and by Gram staining, as well as the search for catalase for Gram + bacteria and oxidase for Gram - bacteria.

Staphylococci thus appear as spheres, at Gram + and catalase +. The affinity factor for fibrinogen or the "clumping factor" or bound coagulase was tested for with the rapid slide test. Free coagulase was not detected by this test. All bacteria producing bound coagulase were identified as $S$. aureus. If the germ was $\beta$-haemolytic and the bound coagulase was negative, free coagulase was tested for with the tube test. Following this second test, all positive colonies were definitively identified as $S$. aureus.

All other bacteria were classified as CNS (coagulase-negative Staphylococci). The CNS were then identified with the study of 20 metabolic, fermentative, $\mathrm{ADH}$ characteristics on Api Staph ${ }^{\circledR}$ galleries from BIOMERIEUX. It is certain that this determination pattern qualifies as $S$. aureus coagulase-positive staphylococci non-aureus (S. intermedius, certain strains of S. hyicus). In addition, some coagulase-positive staphylococci (CPS) were not detected. Thus, all CPS were identified as $S$. aureus in the rest of the study. The identification of CNS at the species level using the Api Staph ${ }^{\circledR}$ galleries was unreliable because of the very limited number of tests used (Bes et al., 1999).

The genera Streptococcus and Enterococcus were identified as Gram + , catalase - and oxidase - cocci. The colonies were then transferred to agar by flooding. Then, the bacterial species were determined by the Api20 Strep ${ }^{\circledR}$ gallery, which explores 20 enzymatic and fermentation properties of the germs. Enterobacteriaceae were identified as
Gram-, catalase + and oxidase - bacilli. Then the identification of the bacterial genus and species was carried out using the Api20 $\mathrm{E}^{\circledR}$ gallery.

Pseudomonas aeruginosa was identified by the presence of blue-green pigments, a Gram negative stain, a catalase + test, and the presence of an oxidase. The use of the Api20NE ${ }^{\circledR}$ gallery allowed the species to be confirmed.

Corynebacteria were identified as Gram+ irregular bacilli. Then, the ApiCoryne $^{\circledR}$ gallery was used.

\section{Statistical Analysis}

Statistical analyses were conducted using SPSS statistical software, with a significance level set at 5\%. The medians of cell counts obtained were analysed over time using the non-parametric Friedman test within Groups 1 and 2 . The means of ISCC obtained on D64 were compared using the nonparametric Wilcoxon-Mann-Whitney test. An independence test of two was applied to bacteriology results on D64 of subgroups A and B of Group 1 to verify the absence or presence of a statistical link between the two distributions.

\section{Results}

In this study, 43 cases of SCM were detected by cell count in Group 1 and were subjected to bacteriological testing. In the first sampling, 23 positive SCC samples were sent to the laboratory, in the second sampling, 12 positive and 11 negative samples were sent, and at the third sampling, 8 positive and 15 negative samples were sent to the laboratory. Therefore, the bacteriological analyses in this study will only concern the samples of Group 1.

Cell counts were conducted on all samples in all three samplings (on D0, D31, and D64) of both groups. The bacteriological results of Group 1 and the cell counts of both groups are presented 
in the first part, while the cell counts of both groups is presented in the second part.

\section{Bacteriological results of Group 1}

Of the 69 samples studied, $26(37.68 \%)$ were bacteriologically negative and $43(62.31 \%)$ quarters were infected. 38 samples $(55.07 \%)$ allowed for the isolation of a single bacterial species, while 31 cases $(44.92 \%)$ gave an association of two or three species. The real prevalence of udder infections at the end of the experiment, i.e., on D64, was 34.78\% (8 positive cases of 23).

\section{Bacteriology on D0}

As mentioned above, of the 68 cows sampled on D0, 23 samples had a cell count greater than or equal to 200,000 cells/ $\mathrm{ml}$ and were bacteriologically examined. These 23 cows constitute Group 1. Of these 23 samples, 6 were mono-bacterial and 17 were bi-bacterial, i.e., $26.08 \%$ and $73.91 \%$, respectively. Starting on D0, this group was divided into 2 subgroups: A (test) and B (control) which were again subjected to bacteriological examinations on D31 and D64.

\section{Subgroup A}

The figure below provides the results of the bacteriology of the sample on D0, i.e., the different bacterial species isolated and their frequencies.

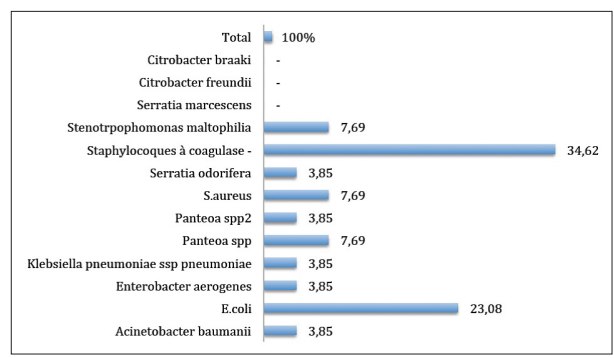

Figure 1. Distribution of the bacterial species isolated alone or in association, during subclinical mastitis on DO, in subgroup $A$
The CNS group was the most frequently isolated type (34.62\%), followed by Escherichia coli (23.08\%), Staphylococcus aureus, Stenotrophomonas maltophilia and Panteoa spp. with $7.69 \%$. Finally, we note that no Streptococcus species were isolated at this stage.

According to the data, the epidemiological model in animal husbandry is the mixed model, associating environmental and contagious mastitis by the presence of different pathogens; CNS and Enterobacteriaceae represented $57.7 \%$ of the isolations. Finally, 11 samples contained two bacterial species in association (three samples contained CNS and E. coli, two samples contained CNS and Panteoa spp., two samples contained $S$. aureus and E. coli, two samples contained CNS and S. maltophilia, and one sample contained each of CNS and Serratia odorifera, and CNS and Acinetobacter baumanii,).

\section{Subgroup $B$}

The figure below provides the results of the bacteriology of the sample on D0, i.e., the bacterial species isolated and their frequencies.

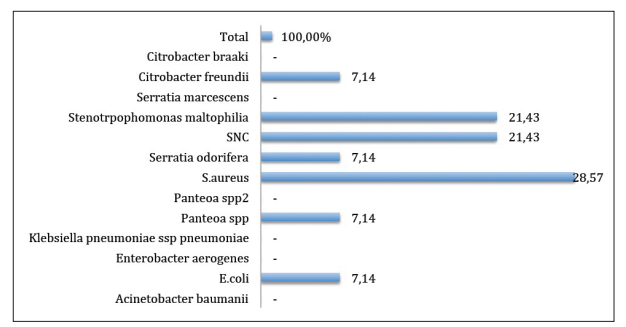

Figure 2. Distribution of the bacterial species isolated alone or in association, during subclinical mastitis on DO, in subgroup $B$

S. aureus was the most frequently isolated bacterium with $28.57 \%$, followed by CNS and Stenotrophomonas maltophilia which were isolated at $21.43 \%$. No Streptococcus species were isolated at 
this stage. Finally, six samples contained two bacterial species in association (two samples contained CNS and S. maltophilia, and one sample each contained $S$. aureus and E. coli, CNS and Serratia odorifera, S. aureus and S. maltophilia, S. aureus and Citrobacter freundii).

\section{Bacteriology on D31}

Bacteriology was performed on the 23 samples initially included in Group 1 , and only 12 were positive on D31. In subgroup $A, 7$ of the initial 15 cows were still positive, giving a decrease in the prevalence of bacterial infection of $53.34 \%$. In subgroup B, 5 of the initial 8 cows were still positive, resulting in a $37.5 \%$ decrease in the prevalence of infection.

\section{Subgroup A}

The figure below shows the isolated bacteria and their frequencies on D31.

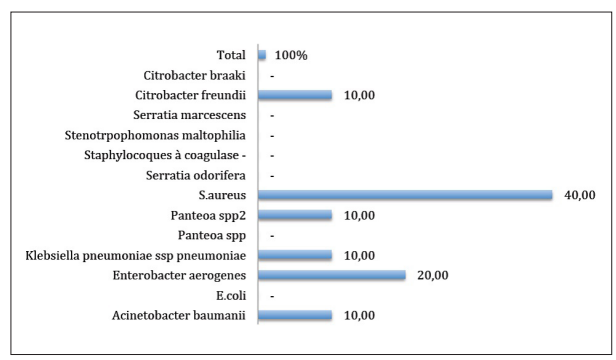

Figure 3. Distribution of the different bacteria isolated alone or in association of subclinical mastitis on D31, within subgroup A

At this stage, S. aureus was the most isolated species with $40 \%$, followed by Enterobacter aerogenes with 20\%. Bacterial associations encountered were: $S$. aureus and Klebsiella pneumoniae spp. pneumoniae, S. aureus and Serratia odorifera, S. aureus and Pantoea spp 2 and Serratia marcescens, $S$. aureus and $S$. maltophilia, S. aureus and Citrobacter freundii and Enterobacter aerogenes.

\section{Subgroup $B$}

Figure 4 shows the isolated bacteria and their frequencies on D31.

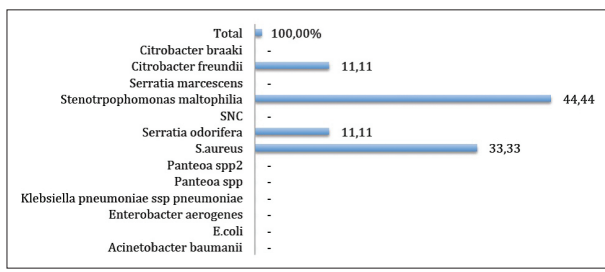

Figure 4. Distribution of the different bacteria isolated alone or in association from subclinical mastitis on D31 in subgroup B

On D31, S. maltophilia was the most frequently isolated species with a percentage of $44.44 \%$, followed by $S$. aureus with $33.33 \%$, Serratia odorifera and Citrobacter freundii were isolated at a frequency of $11.11 \%$. The bacterial associations observed in subgroup B on D31 were: S. aureus and Serratia odorifera, S. aureus and S. maltophilia, S. maltophilia and Citrobacter freundii.

\section{Bacteriology on D64}

Bacteriology was performed on the 23 samples initially included in Group 1, and only 8 were positive on D64: 5 from subgroup A and 3 from subgroup B.

\section{Subgroup A}

Figure 5 shows the isolated bacteria and their frequencies on D64.

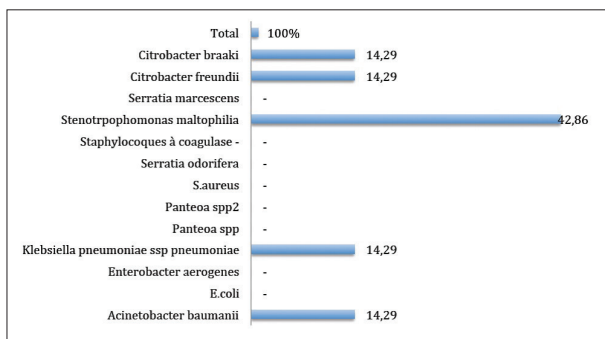

Figure 5. Distribution of the different bacterial species isolated alone or in association, from subclinical mastitis on D64, within subgroup A 
S. maltophilia was the most frequently isolated species with $42.86 \%$ frequency of isolation, followed by Acinetobacter baumanii, Citrobacter braaki, Citrobacter freundii and Klebsiella pneumoniae spp. pneumoniae with $14.29 \%$, respectively. The bacteria isolated in association were: S. maltophilia and Serratia odorifera, C. braakii and $S$. maltophilia and A. baumanii, S. maltophilia and A. baumani, $i$ and $S$. maltophilia and C. freundii.

\section{Subgroup B}

Figure 5 shows the isolated bacteria and their frequencies on D64.

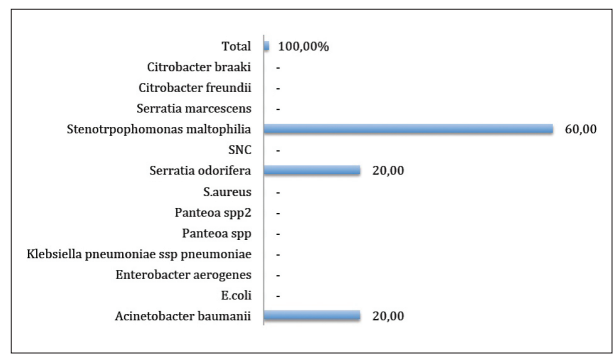

Figure 6. Distribution of the different bacterial species isolated alone or in association, from subclinical mastitis on D64, within subgroup B

S. maltophilia was most frequently isolated with $60 \%$, followed by Serratia odorifera and A. baumanii with $20 \%$. The bacterial species isolated in association were: S. maltophilia and S. odorifera and S. maltophilia and A. baumanii.

\section{Estimation of the bacteriological healing of udders}

The 23 cases of subclinical mastitis which were subjected to three series of bacteriological testing and cell counts were used to make this estimate. To classify the cases as cured/uncured, we considered three cases:

- If the bacteriology on D64 was sterile, regardless of the result of the first bacteriology, the udder was considered to be bacteriologically cured.

- If the result of the bacteriology was the same on D31 and D64 as on D0, the quarter was not cured, and the infection was persistent.

- If the bacterial species isolated on D31 and/or D64 was different from the species isolated on D0, the quarter was considered to be unhealed, with the occurrence of a new infection.

The figure below shows the frequencies of the bacterial species isolated in the first bacteriology for the 23 cases tested.

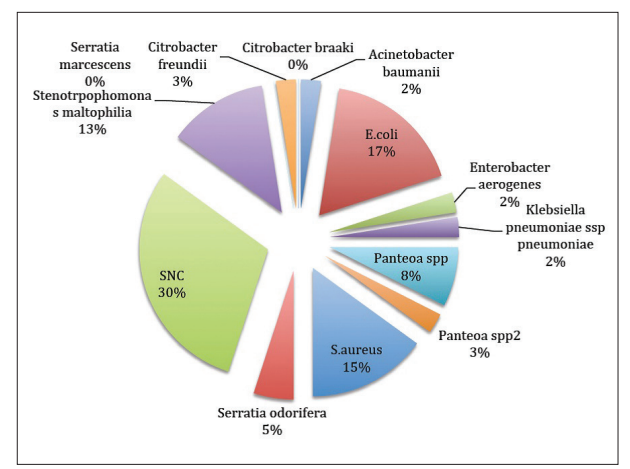

Figure 7. Result of the first bacteriology of the 23 tested cases

\section{Estimated recovery for all bacteria combined}

Subgroup A

Of the initial 15 cases of mastitis on D0, on D64 we observed: 10 recovery cases $(66.66 \%), 2$ persistent infections $(13.33 \%)$, and 3 new infections (20\%).

\section{Subgroup B}

Of the initial 8 cases of mastitis on D0, on D64 we observed: 5 recovery cases (62.5\%), 2 persistent infections (25\%), and 1 new infection $(12.5 \%)$. 
Table 4. Results of ISCC of the three samples for both Groups 1 and 2

\begin{tabular}{|c|c|c|c|c|}
\hline & DO & D31 & D64 & Total \\
\hline$\geq 200,000 \mathrm{cls} / \mathrm{mL}$ & 23 & 12 & 8 & 43 \\
\hline [\%] ISCC $\geq 200,000 \mathrm{cls} / \mathrm{mL}$ & $53.48 \%$ & $27.90 \%$ & $18.60 \%$ & $100 \%$ \\
\hline$<200,000 \mathrm{cls} / \mathrm{mL}$ & 45 & 56 & 60 & 161 \\
\hline (\%) ISCC $<200,000 \mathrm{cls} / \mathrm{mL}$ & $27.95 \%$ & $34.78 \%$ & $37.26 \%$ & $100 \%$ \\
\hline
\end{tabular}

Table 5. ISCC Quartiles on DO in Group 1 (cls/mL)

\begin{tabular}{|c|c|c|}
\hline Variable & ISCC subgroup A & ISCC subgroup B \\
\hline Q1 (1 st $^{\text {quartile })}$ & 209.000 & 209.750 \\
\hline Q2 (median) & 236.000 & 276.000 \\
\hline Q3 (Q3 (3rd quartile) & 270.000 & 362.750 \\
\hline Q3-Q1 & 61.000 & 153.000 \\
\hline
\end{tabular}

\section{Estimated recovery for the most commonly isolated bacteria}

Subgroup A

CNS: Nine cases were analysed, and the bacteriological cure rate was $100 \%$.

$E$. coli: The five cases of initial $E$. coli infection were analysed, and the bacteriological cure rate was $100 \%$.

S. aureus: Two cases were analysed, and the bacteriological cure rate was $100 \%$.

S. maltophilia: Two cases of initial infection with this species were analysed and revealed a $100 \%$ cure rate. However, three new infections were found on D64.

\section{Subgroup B}

CNS: Three cases were analysed and the bacteriological cure rate was $100 \%$.

E. coli: Only case of initial E. coli infection was analysed, and the bacteriological cure rate was $100 \%$.

S. aureus: Four cases were analysed, and the bacteriological cure rate was $100 \%$.

S. maltophilia: Three cases of initial infection with this bacteria were analysed and revealed a $100 \%$ persistence rate of infection, thus a $0 \%$ cure rate.

\section{Milk somatic cell count results}

The Individual Somatic Cell Concentrations (ISCC) measured in three successive samples of milk (on D0, D31, and D64) from both Groups 1 and 2 are shown in Table 10.

\section{Group 1}

ISCC results on D0

Initially on D0, the two subgroups in Group 1 both had an ISCC greater than or equal to $200.000 \mathrm{cls} / \mathrm{mL}$.

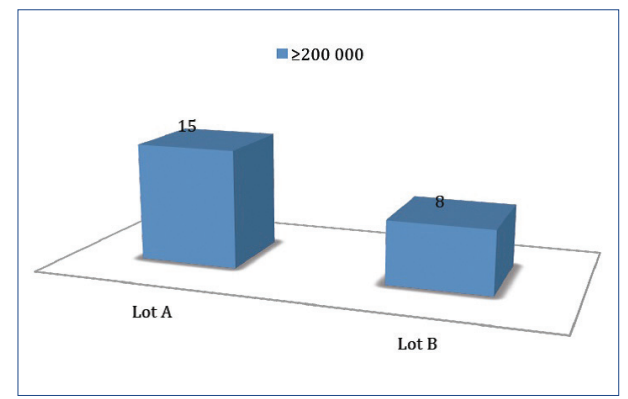

Figure 8. Distribution of ISCC within Group 1 on DO

The quartile diagram of the distribution of ISCC (Table 11) shows 
Table 6. ISCC Quartiles on D31 in Group 1 (cls/mL)

\begin{tabular}{|c|c|c|}
\hline Variable & ISCC subgroup A & ISCC subgroup B \\
\hline Q1 & 18.000 & 49.250 \\
\hline Q2 & 37.000 & 212.000 \\
\hline Q3 & 180.000 & 383.000 \\
\hline Q3-Q1 & 162.000 & 333.750 \\
\hline
\end{tabular}

ISCC results on D64

Table 7. ISCC Quartiles on D64 in Group 1 (cls/mL)

\begin{tabular}{|c|c|c|}
\hline Variable & ISCC subgroup A & ISCC subgroup B \\
\hline Q1 & 30.000 & 44.750 \\
\hline Q2 & 47.000 & 126.500 \\
\hline Q3 & 128.000 & 297.000 \\
\hline Q3-Q1 & 98.000 & 252.250 \\
\hline
\end{tabular}

that $75 \%$ of samples (Q3) had ISCC < $270.000 \mathrm{cls} / \mathrm{mL}$ and ISCC $<362.750 \mathrm{cls} /$ $\mathrm{mL}$ in subgroups $\mathrm{A}$ and $\mathrm{B}$, respectively; thus $25 \%$ of samples (Q1) had ISCC $<$ $209.000 \mathrm{cls} / \mathrm{ml}$ and CCSI $<209.750 \mathrm{cls} / \mathrm{ml}$ in subgroups A and B, respectively.

The median (Q2) of the distribution of ISCC in subgroup A was $236.000 \mathrm{cls} / \mathrm{mL}$, so $50 \%$ of the samples had an ISCC below this median value; and the median (Q2) of the distribution of ISCC in subgroup B was $276.000 \mathrm{cls} / \mathrm{mL}$, so $50 \%$ of the samples had an ISCC below this median value. The observed values of the interquartile range (Q3-Q1) of subgroups $A$ and $B$ are 61.000 and $153.000 \mathrm{cls} / \mathrm{mL}$, respectively.

\section{ISCC Results on D31}

On D31, the proportions were no longer the same as on D0; within the two subgroups $\mathrm{A}$ and $\mathrm{B}$, with 8 and 4 ISCC cases, respectively, below the threshold of $200.000 \mathrm{cls} / \mathrm{mL}$ (below the mastitis threshold).

The quartile distribution of ISCC (Table 6) shows that $75 \%$ of the samples (Q3) had ISCC < $180.000 \mathrm{cls} / \mathrm{mL}$ and ISCC $<383.00 \mathrm{cls} / \mathrm{mL}$ in subgroups A and B, respectively; thus $25 \%$ of the samples (Q1) have ISCC $<18.000 \mathrm{cls} / \mathrm{mL}$ and ISCC $<49.250 \mathrm{cls} / \mathrm{mL}$ in subgroups A and B, respectively.

The median (Q2) of the distribution of ISCC in subgroup A was $37.000 \mathrm{cls} / \mathrm{mL}$, so $50 \%$ of the samples have an ISCC below this median value; and the median (Q2) of the distribution of ISCC in subgroup B is $212.000 \mathrm{cls} / \mathrm{mL}$, so $50 \%$ of the samples have an ISCC below this median value. The observed values of the interquartile range (Q3-Q1) of subgroups A and B are 162.000 and $333.750 \mathrm{cls} / \mathrm{mL}$, respectively.

On D64, drops below the threshold were mainly seen in subgroup A with 3 CCSI (Table 7).

The quartile distribution of the ISCC shows that $75 \%$ of the samples (Q3) had ISCC $<128.000 \mathrm{cls} / \mathrm{mL}$ and ISCC < $297.000 \mathrm{cls} / \mathrm{mL}$ in subgroups A and B, respectively; thus $25 \%$ of the samples (Q1) had ISCC $<30.000 \mathrm{cls} / \mathrm{mL}$ and ISCC $<44.750 \mathrm{cls} / \mathrm{mL}$ in subgroups $\mathrm{A}$ and $\mathrm{B}$, respectively.

The median (Q2) of the distribution of CCSI in subgroup A was $47.000 \mathrm{Cls} / \mathrm{mL}$, so $50 \%$ of the samples had a CCSI below 
Table 8. ISCC Quartiles on DO in Group 2 (cls/ml)

\begin{tabular}{|c|c|c|}
\hline Variable & ISCC subgroup C & ISCC subgroup D \\
\hline Q1 & 9.750 & 22.000 \\
\hline Q2 & 21.500 & 26.000 \\
\hline Q3 & 39.250 & 44.000 \\
\hline Q3-Q1 & 29.500 & 22.000 \\
\hline
\end{tabular}

this median value; and the median $(\mathrm{Q} 2)$ of the distribution of CCSI in subgroup B was $126.500 \mathrm{cls} / \mathrm{mL}$, so $50 \%$ of the samples had a CCSI below this median value. The observed values of the interquartile range (Q3-Q1) of subgroups A and B were 98.000 and $252.250 \mathrm{cls} / \mathrm{mL}$, respectively.

\section{Group 2}

\section{ISCC results on D0}

Initially on D0, both Group 2 subgroups showed an ISCC result of less than $200.000 \mathrm{cls} / \mathrm{ml}$.

The quartile distribution of ISCC showed that $75 \%$ of the samples (Q3) had an ISCC $<39.250 \mathrm{cls} / \mathrm{mL}$ and an ISCC < $44.000 \mathrm{cls} / \mathrm{mL}$ in subgroups C and D, respectively; thus $25 \%$ of the samples (Q1) had an ISCC $<9.750 \mathrm{cls} / \mathrm{mL}$ and ISCC $<22.000 \mathrm{cls} / \mathrm{mL}$ in subgroups $\mathrm{C}$ and $\mathrm{D}$, respectively.

The median (Q2) of the distribution of ISCC in subgroup C was $21.500 \mathrm{cls} / \mathrm{mL}$, so $50 \%$ of the samples have an ISCC below this median value, and the median (Q2) of the distribution of ISCC in subgroup D was $26.000 \mathrm{cls} / \mathrm{mL}$, so $50 \%$ of the samples had an ISCC below this median value.

The observed values of the interquartile range (Q3-Q1) of subgroups $\mathrm{C}$ and D were 29.500 and $22.000 \mathrm{cls} / \mathrm{mL}$, respectively.

\section{CCSI results on D31}

On D31, the proportions were virtually unchanged from D0. In subgroup C, all ISCC remained below the threshold of $200.000 \mathrm{cls} / \mathrm{ml}$, while in subgroup D, only one ISCC exceeded $200.000 \mathrm{cls} / \mathrm{ml}$.
The quartile distribution of ISCC showed that $75 \%$ of samples (Q3) had an ISCC $<57.000 \mathrm{cls} / \mathrm{ml}$ and ISCC $<49.000$ cls/ml in subgroups $C$ and $D$, respectively; thus $25 \%$ of the samples (Q1) had an ISCC $<15.500 \mathrm{cls} / \mathrm{ml}$ and ISCC $<16.000 \mathrm{cls} / \mathrm{ml}$ in subgroups $C$ and $D$, respectively.

The median (Q2) of the distribution of ISCC in subgroup C was $23.500 \mathrm{cls} / \mathrm{ml}$, so $50 \%$ of the samples had an ISCC below this median value; and the median (Q2) of the distribution of ISCC in subgroup D was $24.000 \mathrm{cls} / \mathrm{ml}$, so $50 \%$ of the samples had an ISCC below this median value.

The observed values of the interquartile range (Q3-Q1) of subgroups $\mathrm{C}$ and D were 41.500 and $33.000 \mathrm{cls} / \mathrm{ml}$, respectively.

\section{ISCC results on D64}

On D64, only two ISCC of subgroup C dropped below the threshold.

The quartile distribution of ISCC showed that $75 \%$ of the samples (Q3) had an ISCC $<96.250 \mathrm{cls} / \mathrm{mL}$ and ISCC $<100.000 \mathrm{cls} / \mathrm{mL}$ in subgroups C and D, respectively; thus $25 \%$ of the samples (Q1) had an ISCC $<9.750 \mathrm{cls} / \mathrm{mL}$ and ISCC $<14.000 \mathrm{cls} / \mathrm{mL}$ in subgroups $\mathrm{C}$ and $\mathrm{D}$, respectively.

The median (Q2) of the distribution of ISCC in subgroup C was $38.500 \mathrm{cls} / \mathrm{mL}$, so $50 \%$ of the samples had an ISCC below this median value; and the median (Q2) of the distribution of ISCC in subgroup D was $35.000 \mathrm{cls} / \mathrm{mL}$, so $50 \%$ of the samples had an ISCC below this median value.

The observed values of the interquartile range (Q3-Q1) of subgroups 
Table 9. ISCC descriptive statistics for subgroup A over time

\begin{tabular}{|c|c|c|c|c|c|}
\hline Variable & Observations & Minimum & Maximum & Mean & $\begin{array}{c}\text { Standard } \\
\text { deviation }\end{array}$ \\
\hline D0 & 15 & $135,000.00$ & $310,000.00$ & $235,866.67$ & $46,570.79$ \\
\hline D31 & 15 & 5000.00 & $375,000.00$ & $94,866.67$ & $110,740.93$ \\
\hline D64 & 15 & 2000.00 & $189,000.00$ & $67,933.33$ & $62,349.78$ \\
\hline
\end{tabular}

Table 10. ISCC descriptive statistics for subgroup $\mathrm{C}$ over time

\begin{tabular}{|c|c|c|c|c|c|}
\hline Variable & Observations & Minimum & Maximum & Mean & SD \\
\hline D0 & 30 & $3,000.00$ & $116,000.00$ & $27,533.33$ & $23,998.18$ \\
\hline D31 & 30 & $5,000.00$ & $143,000.00$ & $40,533.33$ & $36,101.14$ \\
\hline D64 & 30 & $4,000.00$ & $747,000.00$ & $84,366.67$ & $148,753.55$ \\
\hline
\end{tabular}

C and D were 86,500 and $86.000 \mathrm{cls} / \mathrm{mL}$, respectively.

\section{Monitoring of cell counts over time}

The purpose of tracking cell counts over time was to evaluate the positive or negative evolution of the ISCC within each group to evaluate the beneficial or negative contribution of SYMBIOVEBA on the recovery of cows initially with SCM (Group 1), and on the prevention of SCM in healthy cows (Group 2).

\section{Group 1}

In Group 1, this analysis concerned subgroup A, which included fifteen cows with SCM that each received a dose of the symbiotic after each sampling session.

According to the table below, the average ISCC on D0 was $235,866.66 \mathrm{cls} /$ $\mathrm{mL}$ and this decreased to $67,933.33 \mathrm{cls} /$ $\mathrm{mL}$ on $\mathrm{D} 64$.

The data revealed that the distribution structure of ISCC changed significantly $(P<0.02)$ over time, improving or decreasing, which may suggest a beneficial effect of the symbiotic on ISCC, and by extrapolation on the recovery of SCM cases (in surpassing the mastitis threshold)

\section{Group 2}

In Group 2, the analysis concerned subgroup $C$ which included thirty cows initially free of SCM and that received a dose of the symbiotic after each sampling session.

The results showed that the average of ISCC on D0 was $27,533.33 \mathrm{cls} / \mathrm{mL}$, which increased to $84,366.33 \mathrm{cls} / \mathrm{mL}$ on D64, but remained below the mastitis threshold. There was a significant difference $(P<0.05)$ in the distribution structure of ISCC over time, though this change was not positive and we cannot conclude that the symbiotic had a preventive effect on subclinical mastitis.

\section{Status of ISCC on D64: evaluation of the symbiotic effect \\ Group 1}

In Group 1, we performed an analysis of recovery rates on D64, as the proportions of udders considered healed compared to unhealed on D64, as shown in the table below.

Table 11. Status of ISCC from Group 1 on D64

\begin{tabular}{|l|c|c|}
\hline & $<\mathbf{S}$ & $\geq \mathbf{S}$ \\
\hline subgroup A & 15 & 0 \\
\hline subgroup B & 5 & 3 \\
\hline
\end{tabular}


Statistical analysis of the data showed a significant difference $(P<0.05)$ between the two distributions of ISCC values on D64, so it can be concluded that SYMBIOVEBA had a curative effect on lactating cows with SCM.

\section{Group 2}

In Group 2, we analysed the preventive effect of the symbiotic with regard to SCM. The proportions of udders considered infected or not on D64 are shown in the table below.

Table 12. Status of ISCC from Group 2 to D64.

\begin{tabular}{|c|c|c|}
\hline & $<\mathbf{S}$ & $\geq \mathbf{S}$ \\
\hline subgroup C & 28 & 2 \\
\hline subgroup D & 15 & 0 \\
\hline
\end{tabular}

Statistical analysis of the data showed $P>0.05$ and therefore the results were not significantly different. In conclusion, this experiment does not offer sufficient argument to conclude that SYMBIOVEBA has a preventive effect on subclinical mastitis.

\section{Analysis of bacteriological recovery rates on D64}

This analysis concerned the bacteriological results of Group 1 on D64. The average recovery rate per cow was $65.21 \%$; specifically, $66.66 \%$ in subgroup $A$ and $62.5 \%$ in subgroup B. We compared the results between the subgroups (Table $24)$ with the chi-squared test $(P=0.84)$.

Table 13. Distribution of recovery at animal level

\begin{tabular}{|c|c|c|}
\hline & Cured & Not cured \\
\hline subgroup A & 10 & 5 \\
\hline subgroup B & 5 & 3 \\
\hline
\end{tabular}

There was no significant difference $(P>0.05)$ between the subgroups in the bacteriological recovery rates per cow. Therefore, from a bacteriological point of view, we cannot assert the curative effect of SYMBIOVEBA on cows with SCM.

\section{Discussion}

In Algeria, several studies have been conducted on the prevalence of subclinical mastitis and the main bacteria responsible for subclinical mastitis in cattle farming (Bouaziz, 2005; Boufaida et al., 2012; Saidi et al., 2013; Saidi et al., 2021a,b). In other countries, feed supplementation with additives to cure lactating cows or prevent possible infection has involved several probiotics (Bouchard, 2013). However, to the extent of our knowledge, studies on symbiotic supplementation and their effect on local immune response during subclinical or non-subclinical infection have not yet been explored.

In this study, the bacteriological recovery rate for Group 1 on D64 was similar to the report by Rajala-Schultze (1983) (68\%). Allaire et al. (1991), in a study of the efficacy of Cepravin ${ }^{\circledR}$ using bacteriology as a diagnostic tool, found a high recovery rate of $88 \%$. Similarly, Allexandre (2005) found bacteriological cure rates of $86 \%$ for Cepravin ${ }^{\circledR}$ and $75 \%$ for Vonapen ${ }^{\circledR}$.

According to the data, the cure rate for staphylococcal infections was higher than those reported by different authors experimenting with antibiotics: $78 \%$ for Laval et al. (1990), 76.9\% for Charpiat (2003). Similar rates were obtained in other studies: 85\% (Cummins and McCasey, 1987), 88\% (Allaire, 1991) and 93\% (Stephan et al., 1984). The divergence of the results can be explained by the fact that Staphylococcus aureus can have intracellular localization and thus become encysted in the parenchyma, meaning that the antibiotic-bacterial contact cannot always occur properly (Bousquet-Mélou, 2003). However, this did not prevent bet- 
ter results in our study due to the composition of SYMBIOVEBA. Indeed, the Lactobacilli were tested in vitro and showed an aptitude to produce components such as organic acids, hydrogen peroxide, and bacteriocins with antimicrobial activity (Nader-Macias et al., 2008; Charlier et al., 2009). Therefore, an intramammary infusion of bacteriocin produced by Lactococcus lactis has shown to be as effective as a conventional antibiotic injection (Crispie et al., 2008; Klostermann et al., 2008).

CNScure rates were $100 \%$ in our study, higher than that reported by Djuricic et al. (2014) (61.29\%). Enterobacteriaceae showed a cure rate of $91.66 \%$, which is similar to the report of Djuricic et al. (2014) $(91.17 \%)$ following intramammary antibiotic injection during lactation.

Curative activity is defined by a CCSI below the cure threshold (S). Recovery is complete if the cleansed udder retains a CCSI $<$ S on D64. The cure rate for all bacterial species combined was $86.95 \%$ in Group 1; it was the total in subgroup A of cows receiving SYMBIOVEBA and $62.5 \%$ in subgroup $B$ of cows not receiving the symbiotic. The difference between the two cure rates was significant, conclusive of the true curative effect of the symbiotic used.

In this study, SYMBIOVEBA had a curative activity quite similar to that of other products reported by various authors: $89 \%$ of quarters treated with cefalexin (Horlacef) for Leroux (1991), 93\% for Allaire (1991) with cephalonium (Cepravin HL), 95\% for Lescut (1999) with cephalonium (Cepravin HL), and 87\% Charpiat (2003) with rifaximin (Fatrox). On the other hand, this rate is higher than those obtained by Saurel (1993) (84\% with cefazolin), Leroux (1991) (79\% with cloxacillin (Orbenin HL) and Charpiat (2003) (77\% with cloxacillin Orbenin). Meissonnier and Laumonier (1991) used individual cell counts to evaluate the efficacy of Vonapen ${ }^{\circledR}$ and observed a significant drop in cell counts for the majority of treated cows from $71 \%$ to $83 \%$.

The cure rate based on CCSI was higher than observed bacteriologically, and this could be explained by the cure threshold set at 200,000 cls/mL, as there may also be bacterial infection below this rate, as reported by Djabri et al. (2002), who stated that quarters with SCCs between 110,000 and 150,000 cls/mL were considered to have minor bacterial infections. This was the case in our study, where samples at CCSI $<$ S present minor bacterial infections (S. maltophilia, Klebsiella pneumoniae, Citrobacter brakii, Citrobacter freundii and Cinetobacter baumanii isolated at: $50 \%, 12.5 \%, 12.5 \%$, $12.5 \%$ frequency, respectively).

Preventive activity was assessed by $\mathrm{CCSI}<\mathrm{S}$ in Group 2 cows. No preventive activity of SYMBIOVEBA was observed in our study due to the non-significant difference between the means of CCSI of the experimental and control subgroups on D64. This may have been due to the small sample size or to the hygienic conditions of milking or breeding.

\section{Conclusions}

To conclude, the combination of CCSI and bacteriological analysis of all cows provided precise and timely information on the aetiology and frequency of subclinical mastitis at the farm. On the other hand, the combination of two of three successive samples offers the possibility of monitoring the present infection, detecting new infections, and estimating the rate of cure with or without treatment.

The administration of SYMBIOVE$\mathrm{BA}^{\circledR}$ to cows suffering from subclinical mastitis during lactation showed a considerable curative effect. The preventive effect of SYMBIOVEBA ${ }^{\circledR}$ on healthy cows against subclinical mastitis was not concluded in our study, and future studies including a larger number of cows and 
over a longer period of time will be necessary to explore its possible preventive activity.

\section{References}

1. ALLAIRE, R., L. EGRON and J. F. ROCHE (1991): Traitement au tarissement de la vache laitière. Utilisation d'une spécialité à longue durée d'action : cepravin. Mammites des Vaches laitières, Société Française de Buiatrie Paris, 18-19 Déc.

2. ALLEXANDRE, A. (2005): Utilisation Des Comptages Cellulaires Dans La Comparaison De Deux Preparations Horslactation. Ecole Nationale Veterinaire De Lyon - Thèse 130.

3. BENIĆ, M., N. MAĆEŠIĆ, L. CVETNIĆ, B. HABRUN, Ž. CVETNIĆ, R. TURK, D. ĐURIČIĆ, M. LOJKIĆ, V. DOBRANIĆ, H. VALPOTIĆ, J. GRIZELJ, D. GRAČNER, J. GRBAVAC and $M$ SAMARDŽIJA (2018): Bovine mastitis: a persistent and evolving problem requiring novel approaches for its control - a review. Vet. Arhiv 88, 535-557.

4. BOUAZIZ, O. (2005): Contribution to the study of intramammary infections in dairy cows in Eastern Algeria. Mentouri University of Constantine, Faculty of Sciences-Department of Veterinary Sciences.

5. BOUCHARD, D. (2013): Probiotic potential of lactic acid bacteria in the bovine mammary ecosystem against Staphylococcus aureus mastitis. Thèse / Université De Rennes 1 sous le sceau de l’Université Européenne de Bretagne.

6. BOUFAIDA, A. Z., M. BUTEL and R. OUZROUT (2012): Prevalence of the main bacteria responsible for subclinical mastitis in dairy cows in northeastern Algeria. Revue d'élevage et de médecine vétérinaire des pays tropicaux 65, 5-9.

7. BOUSQUET-MELOU A. (2003): Antibiothérapie au tarissement : les spécialités disponibles curatives et /ou préventives. Le Point Vétérinaire 235, 19-23.

8. BOUTET, P., F. BUREAU and P. LEKEUX (2006): La mammite bovine: de l'initiation à la résolution. Ann. Méd. Vét. 1-26.

9. BUROVIC, J. (2020): Isolation of bovine clinical mastitis bacterial pathogens. Vet. stn. 51, 47-52. (In Croatian)

10. CHARLIER, J., J. HÖGLUND, G. VONSAMSONHIMMELSTJERNA, P. DORNY and J. VERCRUYSSE (2009): Gastrointestinal nematode infections in adult dairy cattle: impact on production, diagnosis and control. Vet. Parasitol. 164, 70-79.

11. CHARPIAT, O. (2003): Fatroxâ : pour un traitement raisonné au tarissement. Le Point Vétérinaire 235, $27-29$.

12. CRISPIE, F., M. ALONSO-GOMEZ, C. O'LOUGHLIN, K. KLOSTERMANN, J. FLYNN, S. ARKINS, W. MEANEY, R. PAUL ROSS and C. HILL (2008): Intramammary infusion of a live culture for treatment of bovine mastitis: effect of live lactococci on the mammary immune response. J. Dairy Res. 75, 374-384.

13. CUMMINS, K. A. and T. A. MCCASKEY (1987): Multiple Infusions of cloxacillin for treatment of mastitis during during the dry period. J. Dairy Sci.70, 2658-2665.

14. CVETNIĆ, I., M. BENIĆ, B. HABRUN, G. KOMPES, M. STEPANIĆ and M. SAMARDŽIJA (2016a): Most Common Causes of Mastitis in Cows and Goats in Republic of Croatia. Vet. stn. 47, 109-116. (In Croatian).
15. CVETNIĆ, L., M. SAMARDŽIJA, B. HABRUN, G. KOMPES and M. BENIĆ (2016b): Microbiological monitoring of mastitis pathogens in the control of udder health in dairy cows. Slov. Vet. Res. 53, 131-140.

16. CVETNIĆ, I., M. BENIĆ, B. HABRUN, G. KOMPES, M. STEPANIĆ and M. SAMARDŽIJA (2016c): Outbreak and Elimination of Cow Mastitis on a Small Dairy Farm - a Case Report. Vet. stn. 47, 387394. (In Croatian).

17. DJABRI, B., N. BAREILLE, F. BEAUDEAU and H. SEEGERS (2002): Quarter milk somatic cell count in infected dairy cows: a metaanalysis. Vet. Res. 33, 335-357.

18. DJURICIC, D., M. SAMARDZIJA, J. GRIZELJ and T. DOBRANIC (2014): Effet du traitement intramammaire des mammites subcliniques pendant la lactation en élevages bovins laitiers au nord-ouest de la Croatie. Ann. Méd. Vét. 158, 121-125.

19. ĐURIČIĆ, D., M. BENIĆ, N. MAĆEŠIĆ, H. VALPOTIĆ, R. TURK, V. DOBRANIĆ, L. CVETNIĆ, D. GRAČNER, S. VINCE, J. GRIZELJ, J. STARIČ, M. LOJKIČ and M. SAMARDŽIJA (2017): Dietary zeolite clinoptilolite supplementation influences chemical composition of milk and udder health in dairy cows. Vet. stn. 48, 257-265.

20. GRAČNER, D., LJ. BEDRICA, M. CERGOLJ, I. HARAPIN, M. SAMARDŽIJA, G. GREGURIC GRAČNER, D. ŽUBČIĆ, J. REŠETIĆ and M. FURY (2006): Haptoglobinspielel in Blut und Milch von Kuhen mit einer Staphylokokkenmastitis. Tierärtzl. Umsch. 61, 636-641.

21. KLECZKOWSKI, M., W. KLUCIŃSKI, M. CZERSKI and E. KUDYBA (2017): Association between acute phase response, oxidative status and mastitis in cows. Vet. stn. $48,177-186$.

22. KLOSTERMANN, K., F. CRISPIE, J. FLYNN, R. P. ROSS, C. HILL and W. MEANEY (2008) Intramammary infusion of a live culture of Lactococcus lactis for treatment of bovine mastitis: comparison with antibiotic treatment in field trials. J. Dairy Res. 75, 365-373.

23. KOVAČIĆ, M., M. SAMARDŽIJA, D. ĐURIČIĆ S. VINCE, Z. FLEGAR-MEŠTRIĆ, S. PERKOV, D. GRAČNER and R. TURK (2019): Paraoxonase-1 activity and lipid profile in dairy cows with subclinical and clinical mastitis. J. Appl. Anim. Res. 47, 1-4.

24. LAVAL, A., J. D. PUYT, C. DISENHAUS, J. DELAPORTE and B. DELLAC (1990): Utilisation de l'oxacilline dans la prévention et le traitement des mammites bovines hors lactation. Rev. Med. Vet. $141,841-850$.

25. LEROUX, N. (1991): Utilisation de la cefalexine (Horlacef â) dans le tarissement de la vache laitière. Thèse de Doctorat Vétérinaire, Faculté de Médecine, Nantes, $83 \mathrm{p}$.

26. M'SADAK, Y., L. MIGHRI and K. KRAIEM (2014): Study of milk cell counts and descriptive analysis of risk factors for mastitis in above-ground cattle farming in the Monastir region (Tunisia). Nature \& Technology, B- Agronomic and Biological Sciences, pp. 56-61.

27. MACEŠIĆ, N., T. KARADJOLE, G. BAČIĆ, M BENIĆ, M. KARADJOLE, S. VINCE, M. LIPAR, M. CERGOLJ (2012): Aetilogy and prevalence of bovine intramammary infection at drying off. Vet. arhiv 82, 125-131.

28. MAĆEŠIĆ, N., G. BAČIĆ, K. BOŽIĆEVIĆ, M. BENIĆ, T. KARADJOLE, N. PRVANOVIĆ BABIĆ, M. LOJKIĆ, M. EFENDIĆ, I. BAČIĆ, M. PAVLAK (2016): Assessment of the Zagreb mastitis test in diagnosis of subclinical mastitis in dairy cattle. Vet. arhiv 86, 475-485. 
29. MEISSONNIER, E. and G. LAUMONIER (1991): Influence of Vonapen HL on the evolution of milk cell count between dry-off and calving in dairy cows. Mastitis in dairy cows, Société Française de Buiatrie Paris, 18-19 Dec.

30. NADER-MACIAS, M. E., M. C. OTERO, M. C. ESPECHE and N. C. MALDONADO (2008): Advances in the design of probiotic products for the prevention of major diseases in dairy cattle. J. Ind. Microbiol. Biotechnol. 35, 1387-1395.

31. NEDIĆ, S., S. VAKANJAC, M. SAMARDŽIJA and S. BOROZAN (2019): Paraoxonase 1 in bovine milk and blood as marker of subclinical mastitis caused by Staphylococcus aureus. Res. Vet. Sci. 125, 323-332.

32. RAJALA-SCHULTZE, P. J., Y. T. GRÖHN, C. E. MCCULLOCH and C. L. GUARD (1999): Effects of clinical mastitis on milk yield in dairy cows. J. Dairy Sci. 82, 1213-1220.

33. SAIDI, R., D. KHELEF and R. KAIDI (2010): Evaluation of an early detection test for subclinical mastitis in cows. Rev. Elev. Med. Vet. Pays. Trop. 63, 57-61.

34. SAIDI, R., D. KHELEF and R. KAIDI (2010): Bovine mastitis: Prevalence of bacterial pathogens and evaluation of early screening test. Afr. J. Microbiol. Res. 7, 777-782.

35. SAIDI, R., N. MIMOUNE, M. H. BENAISSA, R. BAAZIZI, F. Z. AISSAOUI, M. BEHALIL, D. KHELEF and R. KAIDI (2021a): Camel mastitis in Southern Algeria. Vet. stn. 52, doi.org/10.46419/vs.52.3.9-

36. SAIDI, R., Z. CANTEKIN, N. MIMOUNE, Y. ERGUN, H. SOLMAZ, D. KHELEF and R. KAIDI (2021b): Investigation of the presence of slime production, VanA gene and antiseptic resistance genes in Staphylococci isolated from bovine mastitis in Algeria. Vet. stn. 52, 57-63.

37. SAUREL, P. (1993): Efficacité comparée de la cefazoline et de la cloxacilline dans le traitement et la prévention des mammites chez la vache laitière au tarissement. Thèse de Doctorat Vétérinaire, Université Claude Sabatier, Toulouse $67 \mathrm{p}$.

38. STEPHAN, J., S. T. SCAFFAUX, D. BALLOY and M. PRIKASKY (1984): Prévention et guérison des infections mammaires durant la période de tarissement comparaison de traitements. Rec. Med. Vet. 160, 35-42.

39. TURK, R., C. PIRAS, M. KOVAČIĆ, M. SAMARDŽIJA, H. AHMED, M. DE CANIO, A. URBANI, Z. FLEGAR MEŠTRIĆ, A. SOGGIU, L. BONIZZI and P. RONCADA (2012): Proteomics of inflammatory and oxidative stress response in cows with subclinical and clinical mastitis. J. Proteomics $75,4412-4428$.

40. TURK, R., M. KOLEDIĆ, N. MAĆEŠIĆ, M. BENIĆ, V. DOBRANIĆ, D. ĐURIČIĆ, L. CVETNIĆ and M. SAMARDŽIJA (2017): The role of oxidative stress and inflammatory response in the pathogenesis of mastitis in dairy cows. Mljekarstvo 67, 91-101.

\section{Učinak dodatka prehrani na subklinički mastitis krava}

Imane LAMARI, National high school of veterinary medicine, SPA Laboratory, Algiers, BabEzzouar, Algeria; Nora MIMOUNE, National high school of veterinary medicine, SPA Laboratory, Algiers, Bab-Ezzouar, Algeria, Institute of Veterinary Sciences, Laboratory of Biotechnologies related to animal Reproduction, University of Blida 1, Algeria; Djamel KHELEF, Institute of Veterinary Sciences, Laboratory of Biotechnologies related to animal Reproduction, University of Blida 1, Algeria

Mastitis krava predstavlja važan ekonomski i sanitarni trošak u proizvodnji mlijeka. Prevencija i liječenje ove bolesti u osnovi se temelje na uporabi antibiotika koji negativno utječu na kakvoću mlijeka i čija je učinkovitost ograničena. Cilj je ove studije bio procijeniti učinkovitost alternativnog liječenja na temelju simbioze kontrole i prevencije subkliničkog mastitisa (SCM) te poboljšanja kakvoće mlijeka koje se proizvodi na farmi mlijeka koja se nalazi u sjevernom središtu Alžira. Prikupljeno je mlijeko 68 krava te analizirano prema broju somatskih stanica, a učinjena je i bakteriološka analiza. Izuzeta su tri različita uzorka u intervalu od mjesec dana. Prvi je uzorak izuzet prije davanja dodatka prehrani (SYMBIOVEBA ${ }^{\oplus}$ ) mliječnim kravama u laktaciji. Životinje su klasificirane u 2 skupine kako bi se proučila dva učinka (ljekoviti i preventivni) simbioze. Svaka skupina podijeljena je u dvije skupine, jedna je primala simbiozu, a druga je bila kontrolna skupina. Pojavnost subkliničkog mastitisa na ovoj farmi bila je 33,82 \%. Identifikacija mikroorganizama provedena je klasičnom metodom i odnosila se samo na skupinu krava s mastitisom na početku; to je dopustilo izolaciju 13 različitih mikroorganizama iz tri uzastopno uzorkovana uzorka. Otkrivena je dominacija stafilokoka s učestalošću od $45 \%$ i enterobakterija (40\%). Ovi su postotci bili značajno niži u obje skupine, osim što je to bilo značajnije u liječenih krava: 100 \% izlječenja za stafilokoke i enterobakterije. Broj somatskih stanica u mlijeku pojedine krave (ISCC) ispitan je u sva tri uzorka i u obje skupine je otkrio, za prag uporabe terapije (S) od 200,000 stanica/ $\mathrm{mL}, 100 \%$ postotak izlječenja za skupinu krava koje su primale SYMBIOVEBA ${ }^{\circledR}$ dodatak prehrani u usporedbi sa $62,5 \%$ za kontrolnu skupinu krava $(P<0,05)$.

Ključne riječi: mliječna krava, subklinički mastitis, bakteriologija, BSS u mlijeku pojedine krave, simbioza 